\title{
Zoobenthic community establishment and habitat complexity - the importance of seagrass shoot-density, morphology and physical disturbance for faunal recruitment
}

\author{
Christoffer Boström*, Erik Bonsdorff
}

Åbo Akademi University, Department of Biology, Environmental and Marine Biology, Akademigatan 1, 20500 Åbo, Finland

\begin{abstract}
Seagrass meadows are among the most diverse coastal ecosystems in the Baltic Sea. There is, however, an apparent lack of quantitative data on functional aspects of these systems, such as plant-animal interactions. We tested the importance of seagrass density and morphology for benthic infaunal recruitment in a 2 mo (June/July 1997) field-experiment with both bare and vegetated (3 densities of artificial Ruppia maritima and Zostera marina) colonization trays with azoic sediment. These artificial seagrass patches were placed at $3 \mathrm{~m}$ depth in an unvegetated area of a sandy bottom seagrass site on the Åland Islands, northern Baltic Sea. Faunal succession was followed by SCUBAdiving and core sampling with 10 to 20 d intervals. The data showed strong effects of seagrass complexity and wind disturbance on (1) physical processes such as accumulation of drifting algae, particle trapping and sediment binding, (2) development of community parameters (abundance, species richness, diversity) and (3) species-specific colonization patterns. Our data further demonstrated the importance of post-settlement events for distribution of juvenile macrofauna (e.g. resuspension or transport by means of drifting algae), and showed negative and positive effects of wind-mediated disturbance in low- and high-complexity habitats, respectively. It is concluded that wind disturbance may act as a mechanism creating and maintaining high animal diversity in seagrass meadows.
\end{abstract}

KEY WORDS: Zostera marina - Ruppia maritima $\cdot$ Artificial seagrass · Invertebrate assemblage · Physical disturbance $\cdot$ Field experiment $\cdot$ Drifting algae $\cdot$ Baltic Sea

\section{INTRODUCTION}

In seagrass ecosystems, alterations in vegetation complexity occur frequently as a result of natural or man-induced disturbances (e.g. wind, waves, accumulation of algae, ice-scouring, dredging) or biological events such as variations in seagrass growth, burrowing fauna or herbivory. Such processes change the above and/or below-ground complexity for associated invertebrates, and result in varying spatial and temporal successional patterns (Thrush et al. 1998).

To date, emphasis of manipulative or experimental seagrass studies has been on the effects of seagrass

${ }^{*}$ E-mail: christoffer.bostrom@abo.fi density or leaf architecture on fish and/or decapod recruitment and abundance (Bell \& Westoby 1986a,b, Bell et al. 1987, Sogard 1989, Worthington et al. 1992, Jenkins \& Sutherland 1997, Rooker \& Holt 1997, Rooker et al. 1998, Horinouchi \& Mitsuhiko 1999). Effects of epibenthic structure (both natural and artificial vegetation) have also been related to meiofaunal behaviour and colonization (Palmer 1986, 1988, Cummings \& Ruber 1987, Hicks 1989, Bell \& Hicks 1991, Walters \& Bell 1994, Guerrini et al. 1998) and enhanced bivalve settlement in seagrass meadows (Peterson 1986, Eckman 1987, Wilson 1990, Reusch \& Chapman 1995, Grizzle et al. 1996, Reusch 1998). However, infaunal macrobenthic assemblage development in relation to artificial seagrass complexity has received less atten- 
tion (Eckman 1983, Eggleston et al. 1999), and is poorly understood, especially in sub- or non-tidal systems.

Models of mechanisms leading to higher animal abundances in seagrass provide contrasting evidence on the importance of active versus passive dispersal and recruitment (Orth 1992). Active dispersal includes migrations within and between patches of seagrass and choice of suitable habitat (Virnstein \& Curran 1986, Sogard 1989), while passive recruitment is driven by the hydrodynamic environment modified by seagrass, which may alter the supply and deposition of particles and thus also of juveniles or larvae of macrofauna (Eckman 1983, Ward et al. 1984, Fonseca \& Fisher 1986). For meiofauna, the importance of active or passive dispersal and recruitment may vary, depending on taxonomic composition, hydrodynamics, disturbance or above-ground structure (Palmer 1988).

The coastal areas of the non-tidal Baltic Sea provide relatively simple model systems for seagrass-related studies (Boström \& Bonsdorff 1997). In these areas, eelgrass Zostera marina forms distinct patches (commonly $<300$ shoots $\mathrm{m}^{-2}$ ) on bare sand, and may co-occur with structurally differing phanerogams (e.g. Ruppia maritima, Potamogeton pectinatus, Zannichellia palustris, Myriophyllum spicatum). These floral characteristics, combined with low structural and functional diversity of the benthos (Bonsdorff \& Pearson 1999), a short spawning period (strong seasonality), and low proportion of pelagically reproducing benthic species, facilitate experimental testing of complexity-related hypotheses at population and community levels. Across the Baltic Sea, Z. marina meadows are threatened or reduced by eutrophication and are in urgent need of mapping, monitoring, and conservation measures (Schramm 1996, Boström \& Bonsdorff 1997, Worm et al. 1999). Compared to bare substrates, these habitats harbour rich invertebrate communities (Boström \& Bonsdorff 1997), but there is an apparent lack of quantitative data focusing on functional aspects, such as plant-animal interactions.

This paper reports experimental evidence on the importance of seagrass meadows for zoobenthic colonization and community development, and tests the null-hypothesis that seagrass complexity (density and leaf architecture) has no effect on faunal recruitment.

\section{MATERIALS AND METHODS}

Study area. In the island-rich archipelago of Åland (northern Baltic Sea), sandy beaches are rare and constitute only about $0.3 \%$ (i.e. $75 \mathrm{~km}$ ) of the total coastline (Granö \& Roto 1991). However, along the Finnish coast, shallow (0 to $10 \mathrm{~m}$ ) sandy bottom areas may locally (e.g. Pori, NW Åland, Hanko and Kotka) exceed several square kilometers, but the area covered by seagrass meadows is restricted to the upper sublittoral (1 to $5 \mathrm{~m}$ ). We studied a shallow (mean depth $2.5 \mathrm{~m}$ ) sandy bight on the west coast of the Aland Islands (Hinderbengtsviken, Eckerö: $60^{\circ} 10^{\prime} \mathrm{N}, 20^{\circ} 32^{\prime}$ E; Fig. 1). Sites such as this are rare, and thus far not described in detail. From a conservational point of view, the site represents a valuble but threatened coastal habitat worthy of protection. The site is situated $<10 \mathrm{~km}$ from the deepest $(290 \mathrm{~m})$ basin in the northern Baltic Sea, and is directly exposed to the dominating wind direction (SW: Fig. 1). Consequently, occasional strong winds, cold-water pulses ( 3 to $\left.5^{\circ} \mathrm{C}\right)$, and large, wind-induced spatio-temporal variability in the coverage of benthic drift algal mats are common phenomena. During summer, mostly filamentous algae occur and may cover large areas of the bottom, while large amounts of detached brown alga Fucus vesiculosus dominate in autumn and winter. Because of its position and exposure, the site has good potential for the entry of planktonic recruits. The rooted vegetation grows only on the western half of the bight, forming a sharp boundary between vegetated and bare sand (Fig. 1). However, bare patches within the vegetation ('blow-outs') also occur. At 1 to $2 \mathrm{~m}$ depth, mixed meadows of Zostera marina, Potamogeton spp. and Zanichellia spp. are common, while pure $Z$. marina meadows dominate at 2 to $5 \mathrm{~m}$ depth. The average shoot density of $Z$. marina is about $250 \mathrm{~m}^{-2}$ (range: 50 to $500,50 \times 50 \mathrm{~cm}$ frame, $\mathrm{n}=48$ ). Ruppia maritima grows at 0.5 to $3 \mathrm{~m}$ depth, and forms distinct monospecific patches about 0.5 to $1.5 \mathrm{~m}$ in diameter. Even though the density of $R$. maritima at this site may exceed 1000 shoots $\mathrm{m}^{-2}$, both the aboveground ( $<10 \mathrm{~cm}$ long, 1 to $2 \mathrm{~mm}$ narrow leaves) and the below-ground ( 2 to $5 \mathrm{~cm}$ deep mat of thin rhizomes) structure of this species remains fairly simple, compared to the more physically complex $Z$. marina habitat (20 to $60 \mathrm{~cm}$ long, 3 to $5 \mathrm{~mm}$-wide leaves, 10 to $20 \mathrm{~cm}$ deep rhizome mat).

These seagrass meadows, low in genetic diversity (Reusch et al. 1999), facilitate the existence of diverse invertebrate assemblages in the otherwise speciespoor sandy sediments (Fig. 2). Hence, in a preliminary field study (diving and core-sampling in 1996), high densities of newly settled baltic clams (Macoma balthica: 55000 individuals $\mathrm{m}^{-2}$, representing almost $35 \%$ of the total invertebrate abundance) were recorded in both the small Ruppia maritima patches and in the more extensive Zostera marina meadows ( 5000 individuals $\mathrm{m}^{-2}, 12 \%$ of total abundance), demonstrating the potential importance of these seagrasses for zoobenthic settlement and recruitment (Fig. 2). The area is also rich in benthivorous fishes, but no attempt to exclude this possible structuring factor (Sogard 1984, Aarnio \& Bonsdorff 1993, Aarnio et al. 1996) from the 


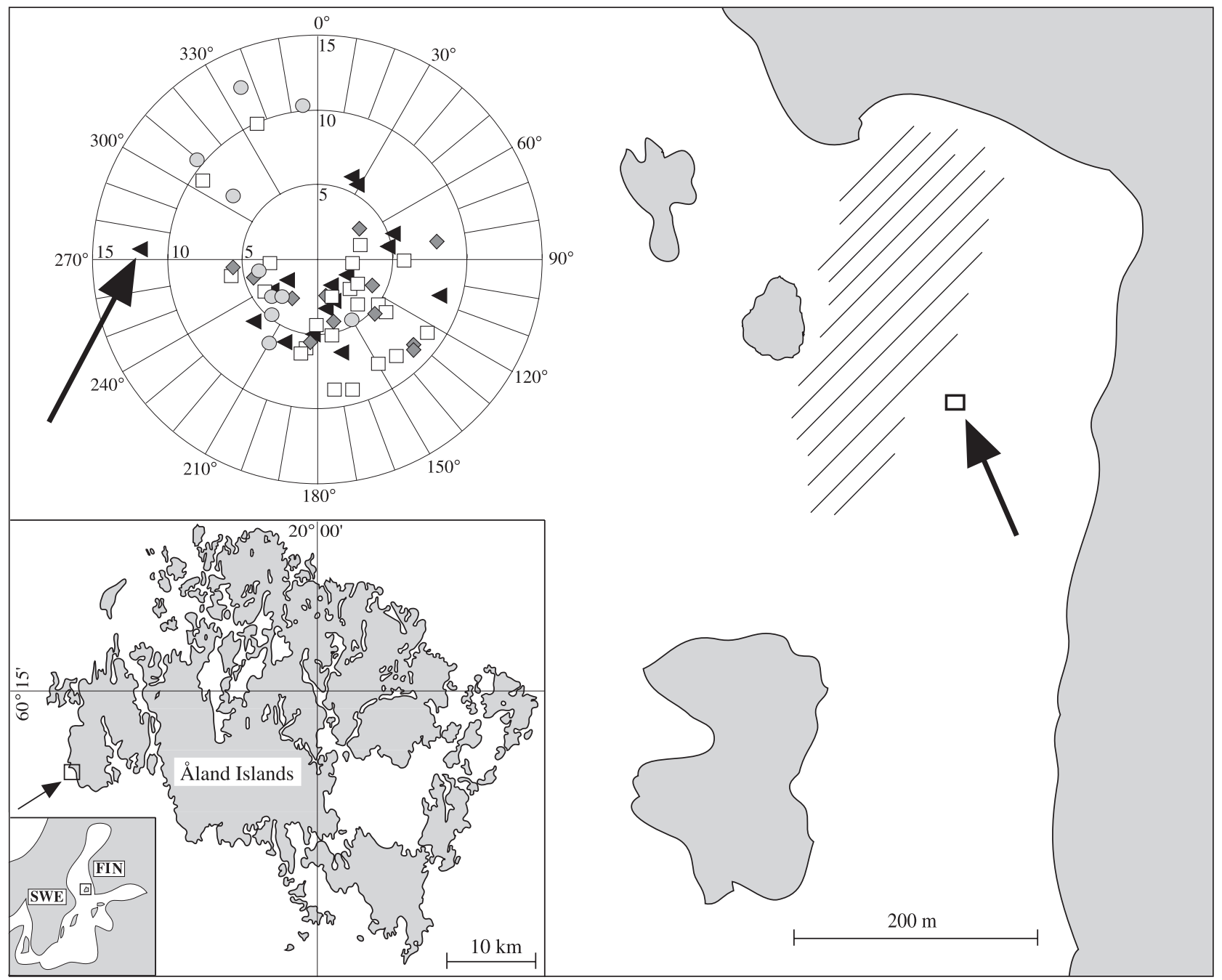

Fig. 1. Location of study site, Hinderbengtsviken $\left(60^{\circ} 10^{\prime} \mathrm{N} ; 20^{\circ} 32^{\prime} \mathrm{E}\right)$, Åland Islands, northern Baltic Sea, and wind direction and speed ( $\mathrm{m} \mathrm{s}^{-1}$ ) during study period (1997) (summarized in wind compass). ( $\square$ ) Period I (4 to 25 June); ( $\diamond$ ) Period II (26 June to 7 July), (○) Period III (8 to 17 July), (४) Period IV (18 to 31 July). The upper left arrow indicates strong western winds in Period IV, right arrow position of experimental area. The dashed area in the western half of the bay indicates the approximate distribution of seagrass

experimental area was made (see following subsection: 'Experimental design'). Hence, above the upper distribution limit of seagrasses, the bare surf zone supports more fishes than the surf zone of the unvegetated side. Deeper, in the bare (eastern) half of the bay, flounder Platichtys flesus, turbot Scophthalmus maximus, gobies Pomatoschistus minutus and P. microps, and schools (>500 individuals, quantified by underwater photography) of sandeel Ammodytes tobianus dominate, while common species in the vegetated (western) part of the bay are pipefish Nerophis ophidion and Sygnathus typhle, sticklebacks Gasterosteus aculeatus, Pungitius pungitius and Spinachia spinachia, and eelpout Zoarces viviparus. These faunal distibutional patterns, coupled to the apparent differences in the above-ground leaf morphology of $R$. maritima and
Z. marina, provided the framework for our experimental design.

Experimental design. In order to study the importance of seagrass leaf morphology and density for faunal settlement, we created artificial seagrass units by planting 2 types of seagrass mimics in 3 densities into colonization trays filled with azoic sediment (commercial sand, grain size $=48.1 \% \geq 0.25 \mathrm{~mm}, 41.6 \%$ $\geq 0.5 \mathrm{~mm}, 9.9 \% \geq 0.125 \mathrm{~mm}, 0.4 \% \geq 0.074 \mathrm{~mm})$. The control treatment consisted of trays with unvegetated sediment. Thus, Factor A (morphology) had 2 levels (Ruppia maritima, Zostera marina) and Factor B (density) 3 levels (low, medium, high). This $2 \times 3$ factorial design consisted of 35 trays ( 7 treatments each replicated 5 times), which in the field were placed in a randomized block pattern. The treatments were: $R$. mar- 

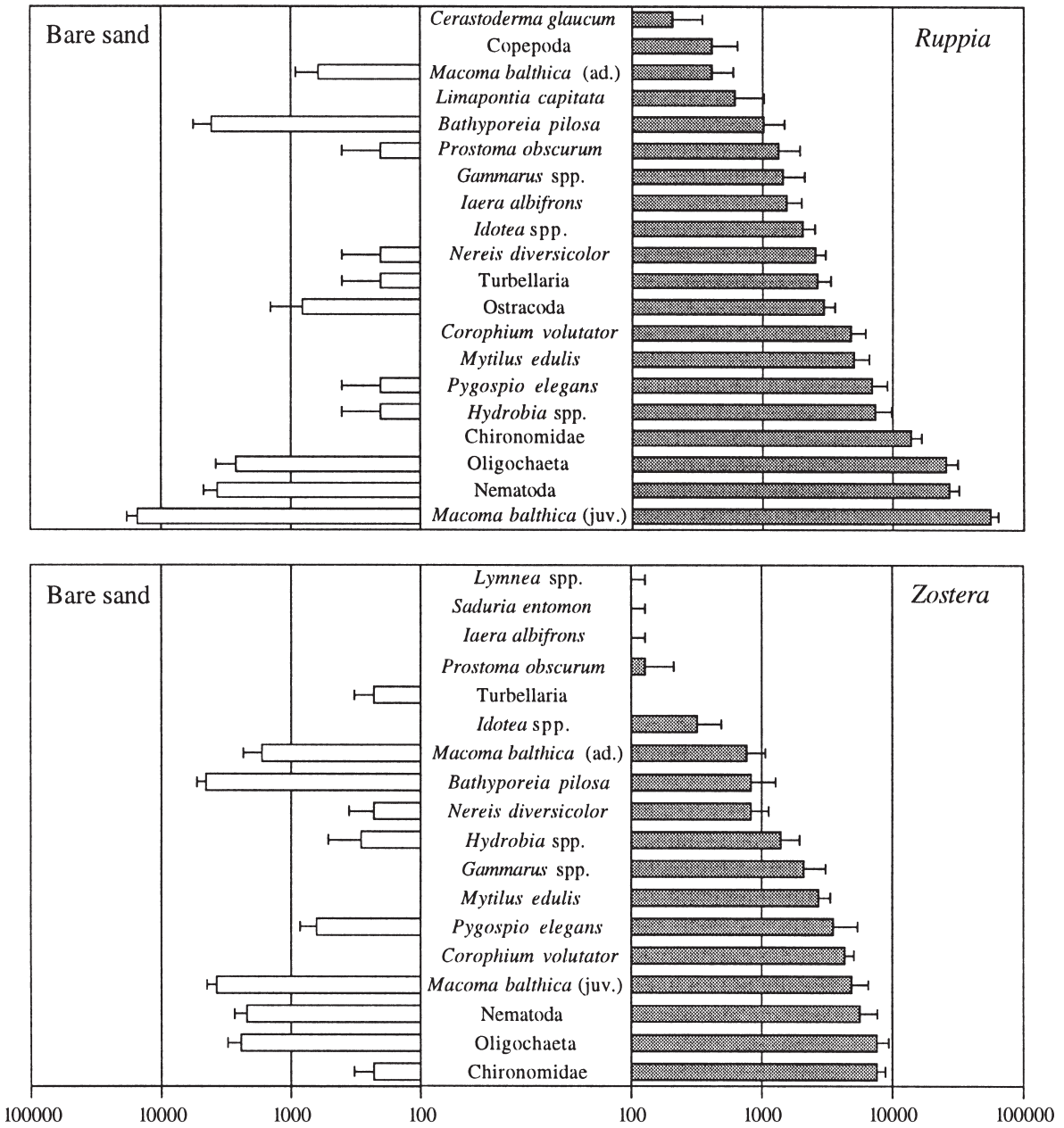

Fig. 2. Infaunal community composition of Ruppia maritima patches, Zostera marina meadows, and bare sand area of study site (pilot study, summer 1996). $R$. maritima: sampling depth 1 to $2 \mathrm{~m}$, corer $2.5 \mathrm{~cm} \varnothing$, $5 \mathrm{~cm}$ deep, sieve $0.25 \mathrm{~mm} ; Z$. marina: sampling depth 2 to $3 \mathrm{~m}$, corer $4.5 \mathrm{~cm}$ $\varnothing, 10 \mathrm{~cm}$ deep, sieve $0.5 \mathrm{~mm}$. Total abundance in $R$. maritima and $Z$. marina $=165000$ and 44000 individuals $\mathrm{m}^{-2}$, respectively. Taxa ranked in order of increasing numerical importance. Scale is logarithmic. ad: adults; juv: juveniles

Number of individuals $\mathrm{m}^{-2}$

itima low density (RL), $R$. maritima medium density (RM), R. maritima high density (RH), Z. marina low density (ZL), Z. marina medium density (ZM), $Z$. marina high density (ZH) and bare sand (BS), which served as a control. Details of the experimental design are given in Table 1.

The Ruppia maritima shoots were made of circular plastic brush bristles $(\varnothing 1 \mathrm{~mm})$. These bristles were folded, resulting in $10 \mathrm{~cm}$-long shoots consisting of 2 narrow leaves. The Zostera marina mimic shoots were made of $5 \mathrm{~mm}$ wide (0.5 mm thick) polypropylene wrapping ribbon. A shoot mimic consisted of two $25 \mathrm{~cm}$-long blades, i.e. a $50 \mathrm{~cm}$ piece of plastic ribbon folded once. The experimental seagrass units were made of circular plastic trays $(51 \mathrm{~cm}$ across, $5.3 \mathrm{~cm}$ deep, area $0.2 \mathrm{~m}^{-2}$ ). First, the artificial seagrass was attached to a $20 \mathrm{~mm}$ thick, circular polyurethan sheet by pushing the shoots through the sheet. This resulted in a very rigid leaf-base unit. This unit was then pressed tightly into each experimental tray and covered with azoic sand. The sediment layer was $3 \mathrm{~cm}$ thick and of contrasting color (dark red Rapakivi granite) to the greyish white sand ( 80 to $85 \%$ quartz) at the study site; this enabled observation of sediment transport during the experiment (see following subsection). Since all seagrass mimics consisted of rigid plastic, this design gave erect seagrass structures which also enhanced stabilization of the azoic sediment, mimicking the below-ground stability normally provided by rhizomes. By using stiff leaf-mimics we also avoided the negative effects (sweeping of the sediment surface) of flexible leaf mimics recorded for meiofaunal colonization (Hicks 1989). However, the complex biotic impact in terms of production, decay and release of organic matter and photosynthetic oxygen production and respiration of living seagrass beds could not be included in this experimental design. In the field, the trays were placed at $3 \mathrm{~m}$ depth in an unvegetated area about $30 \mathrm{~m}$ from the nearest seagrass meadow (Fig. 1). Each tray was anchored with 3 galvanized metal hooks $(30 \mathrm{~cm}$ in length) pushed $25 \mathrm{~cm}$ into the sediment. The distance between trays and rows was $1 \mathrm{~m}$, covering a total 
Table 1. Above-ground leaf characteristics of artificial seagrasses (Ruppia maritima and Zostera marina) used in experiment. Diameter refers to circular $R$. maritima shoots, width to strap-like Z. marina shoots

\begin{tabular}{|c|c|c|c|c|c|c|}
\hline \multirow[t]{2}{*}{ Parameter } & \multicolumn{3}{|c|}{ Ruppia (R) } & \multicolumn{3}{|c|}{ Zostera (Z) } \\
\hline & Low (L) & Medium (M) & $\operatorname{High}(\mathrm{H})$ & Low (L) & Medium (M) & $\operatorname{High}(\mathrm{H})$ \\
\hline Length (mm) & 50 & 50 & 50 & 200 & 200 & 200 \\
\hline Diameter/width (mm) & 1 & 1 & 1 & 5 & 5 & 5 \\
\hline Area $\left(\mathrm{cm}^{-2}\right)$ & 3 & 3 & 3 & 40 & 40 & 40 \\
\hline Density tray ${ }^{-1}$ & 20 & 58 & 176 & 20 & 58 & 176 \\
\hline Density $\mathrm{m}^{-2}$ & 100 & 300 & 900 & 100 & 300 & 900 \\
\hline Leaf spacing (mm) & 120 & 60 & 40 & 120 & 60 & 40 \\
\hline Shoot area $\left(\mathrm{cm}^{2}\right)$ tray $^{-1}$ & 63 & 182 & 553 & 800 & 2320 & 7040 \\
\hline Shoot area $\left(\mathrm{cm}^{2}\right) \mathrm{m}^{-\frac{1}{2}}$ & 320 & 927 & 2816 & 4074 & 11816 & 35855 \\
\hline
\end{tabular}

area of $61.75 \mathrm{~m}^{-2}(9.5 \times 6.5 \mathrm{~m})$. This design allowed 2 SCUBA divers to carefully operate between rows and to sample all units during 1 dive (bottom time approx. $60 \mathrm{~min}$.).

Sampling and processing. The colonization period lasted 57 d (4 June to 31 July 1997), and was timed to coincide with the peak in invertebrate settlement. The seagrass units were sampled 4 times, at Days 21, 33, 43 and 57 . On each sampling occasion, 1 infaunal core ( $\varnothing 2.5 \mathrm{~cm}, 3 \mathrm{~cm}$ deep) was haphazardly taken at least $5 \mathrm{~cm}$ from the edge of each tray to avoid possible edge effects (Thrush et al. 1996, Petersen et al. 1999). In addition, a visual estimate of the percental coverage of drifting algae (made independently by 2 divers) and percentage sediment increase/loss was made. On each occasion, we also recorded by visual observation mobile macrofauna and fishes associated with the artificial seagrass units. Water temperature (minimum/ maximum thermometer attached to the bottom) and other basic hydrographical parameters ( $\mathrm{pH}$ and salinity) were recorded on each sampling occasion. In the laboratory, samples were fixed in buffered formalin (4\%), sieved through $250 \mu \mathrm{m}$ mesh, and then sorted, identified (to species level where possible), and counted under a dissecting microscope.

Data analysis. All community data met assumptions for parametric testing (normality; Shapiro-Wilk $W$-test for homoscedasticity; Bartlett's test) and were subjected to 4 separate ( 1 for each date) analysis of variances. For practical reasons, we used only 1 set of replicate controls, causing asymmetry to the design (Underwood 1997). To test for differences among levels, significant results $(p<0.05)$ from the ANOVA were examined with the Student-Newman-Keuls (SNK) test. Data on daily wind speed $\left(\mathrm{m} \mathrm{s}^{-1}\right)$ is based on recordings from Weather Station Märket (Finnish Meteorological Institute), situated about $10 \mathrm{~km}$ from the study site. Recordings of $<3 \mathrm{~m} \mathrm{~s}^{-1}$ were not included. At Day 55, strong westerly winds (Fig. 1) resulted in considerable sediment loss in the BS and RL treatments (see 'Results'). Samples from these treatments were not considered representative, and therefore not included in the further analysis. When testing for possible effects of the position of treatments (1-way ANOVA for each date, 'block' as factor) on total abundance and species richness, no significant effects were found (abundance: $\mathrm{p}=0.53$ to 0.90 ; species richness: $\mathrm{p}=0.41$ to 0.89 ). Diversity was measured by the Shannon-Wiener diversity index $\left(H^{\prime}\right)$ using logarithm base 2 (Shannon \& Weaver 1963). To illustrate similarity (Bray-Curtis) between treatments over time, all species-abundance data (including rare species) from the individual core samples were square-root-transformed in order to correct for numerically dominating taxa, and analysed in PRIMER. Comparisons of differences among dates or among treatments were performed using paired or unpaired Student's $t$-tests, respectively. All mean values are given with $\pm 1 \mathrm{SE}$.

\section{RESULTS}

\section{Environmental conditions}

The sampling period was characterized by light southeastern winds (Fig. 1) and warm, sunny weather. The average water temperature during the experiment was about $17^{\circ} \mathrm{C}$, but varied greatly: at the start of the experiment the temperature was $3^{\circ} \mathrm{C}$ due to a coldwater pulse, but exceeded $20^{\circ} \mathrm{C}$ towards the end of the experiment. Salinity was 6.5 psu (range: 6.3 to 6.8 ) and pH 8.3 (range: 7.9 to 8.9 ). The mean wind velocity during the experimental period was 5 to $7 \mathrm{~m} \mathrm{~s}^{-1}$, and almost $70 \%$ of all recordings were $<6 \mathrm{~m} \mathrm{~s}^{-1}$ (Fig. 1). Days with stronger winds $\left(>10 \mathrm{~m} \mathrm{~s}^{-1}\right)$ were common, except in Period II (26 June to 7 July), when the mean wind velocity was $5.2 \mathrm{~m} \mathrm{~s}^{-1}$. However, since the site is exposed towards the south and west (Fig. 1), only the intensive western winds (mean velocity $11.3 \mathrm{~m} \mathrm{~s}^{-1}$ ) on Days 55 and 56 affected the experiment (see, e.g., subsection 'Sediment stabilization by artificial seagrass' below). 


\section{Trapping of drifting algae}

Benthic mats of drifting algae frequently occurred at the study site throughout the experimental period. The species composition of these mats was dominated by fragments of filamentous green and brown algae Cladophora glomerata, C. rupestris and Pilayella littoralis and red algae Ceramium tenuicorne and Polysiphonia fucoides. The algae easily became entangled in the artificial seagrass. On Day 21, tufts of algae were trapped around the shoot base of both the Ruppia maritima and Zostera marina mimics, but later, algae also occurred on the bare sediment among the shoots. The coverage of drifting algae was always higher in the seagrass treatments than in the bare sand control (Fig. 3a), and this pattern was constant during the whole experimental period. The coverage of algae in the BS treatment remained low $(<5 \%)$. The loose-lying algal mats entered the artificial $Z$. marina units less effectively. Consequently, the mean algal coverage during the whole period was higher in the $R$. maritima
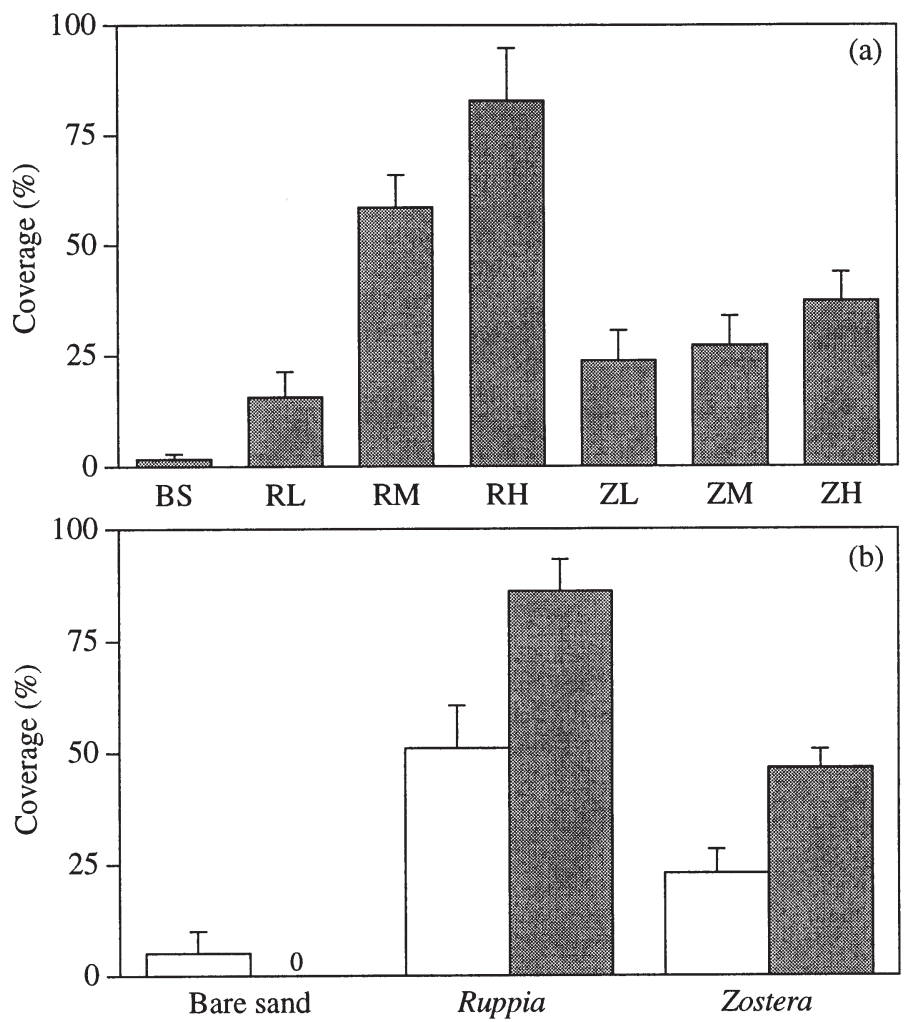

Fig. 3. (a) Mean percentage coverage of drifting algae in bare sand (control treatment) and in different densities of artificial Ruppia maritima and Zostera marina during study period. (b) Pooled percentage estimates of coverage of drifting algae in sand (control treatment), artificial $R$. maritima and Z. marina before (open bars, Day 43) and after (shaded bars, Day 57) disturbance by strong winds. For treatment abbreviations see Table 3 legend treatments (52\%) than in Z. marina treatments (30\%) and, especially in the $R$. maritima treatments, the percentage algal cover increased as a function of shoot density (Fig. 3a). After the strong westerly winds, the algal cover increased in all treatments. Based on pooled data of all 3 densities of both $R$. maritima and $Z$. marina, the coverage of drifting algae had increased by almost $100 \%$ in both vegetation types from Day 43 (before wind disturbance) to Day 57 (after wind disturbance) (Fig. 3b).

\section{Sediment stabilization by artificial seagrass}

The response to the strong winds in terms of sediment loss or increase differed among treatments. Generally, sediment loss was more pronounced in the Ruppia maritima treatments than in the Zostera marina treatments. The BS and RL treatments showed the poorest sediment retention, illustrated by red-coloured experimental sediment outside these units. Consequently, on Day 57 , also 3 to $5 \mathrm{~cm}$ deep ripple marks were observed in the ambient sand area and the lowcomplexity treatments experienced substantial sediment loss (80 to $100 \%$ ), with a crash of the newly established community (no sampling possible; see Figs. 4 \& 5). The mean percentage losses of sediment in the more complex treatments were less pronounced (RM $40 \%$, ZL $50 \%$, ZM 15\%). In contrast, because of wind action on Days 55 and 56, the amount of contrasting-coloured ambient sediment in the $\mathrm{RH}$ and $\mathrm{ZH}$ treatments increased by an average of 15 and $10 \%$, respectively.

\section{Total abundance and species richness}

Faunal recrutiment to the experimental units was not random, since the seagrass units with the highest shoot density collected most species. Especially in the high-complexity treatments, both these parameters increased rapidly during the 2 mo colonization period. Thus, by Day 57, total abundance had increased by 2 orders of magnitude (from 7000 to 700000 individuals $\mathrm{m}^{-2}$ ), and species numbers from 2 to 12 in the RH and ZH treatments (Fig. 4). At an early successional stage (after $3 \mathrm{wk}$ ), the variability of both community parameters among treatments was high. No effects of the main factors were recorded, and none of the seagrass treatments differed significantly from the bare sand control (Fig. 4, Table 2). After nearly 5 wk, there was a significant effect of shoot density $(\mathrm{p}<0.05)$ on total abundance (Table 2), and on Day 33 both RH and ZH exceeded 30000 individuals $\mathrm{m}^{-2}$ (Fig. 4a). Since the unvegetated control (BS) had by this day also reached 

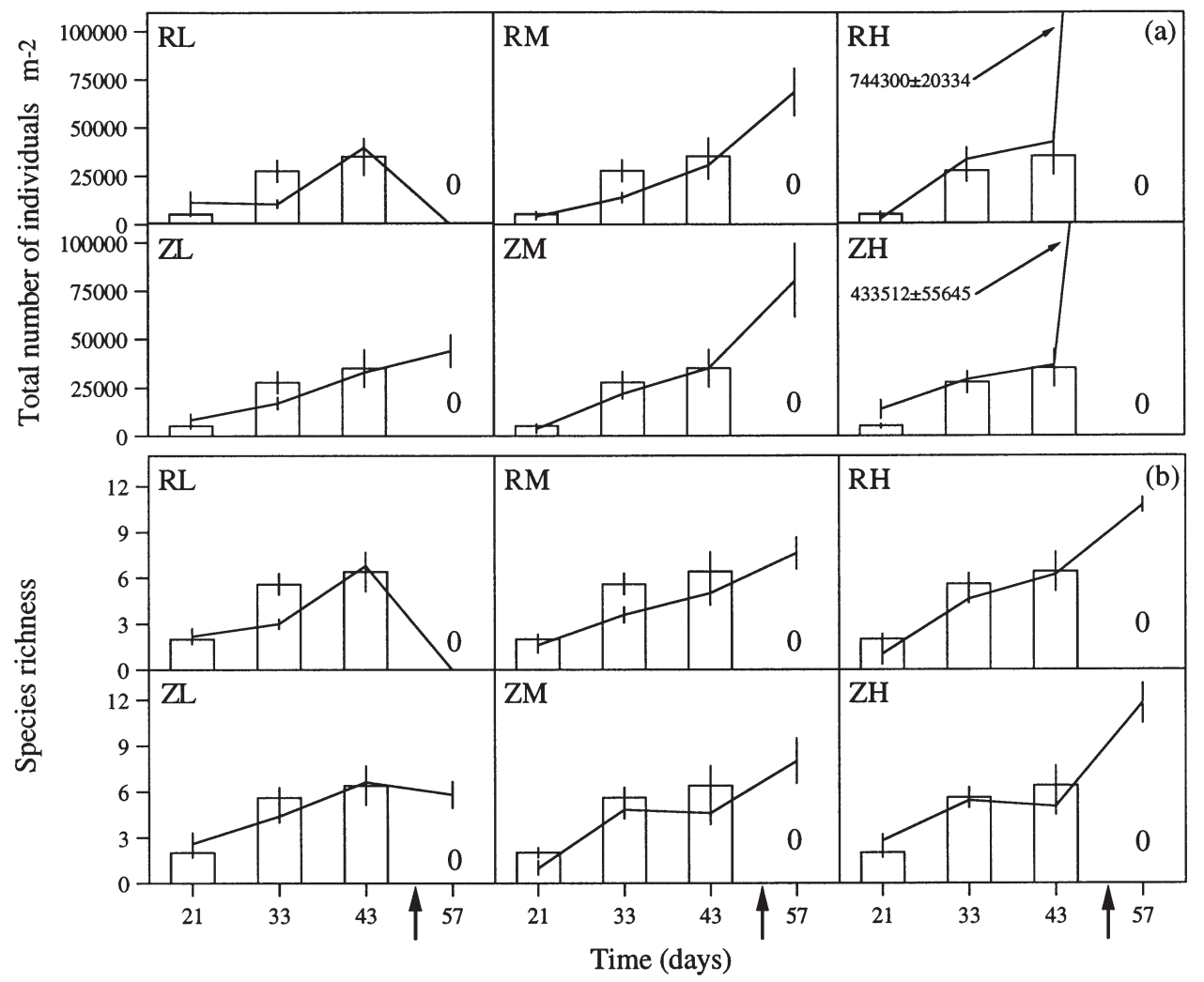

Fig. 4. Development of total abundance (a) and species richness (b) in artificial seagrass units during $57 \mathrm{~d}$ experiment. Lines represent seagrass treatments, histograms bare sand controls. Timing of disturbance by strong winds is indicated by arrows on $x$-axis. For treatment abbreviations see Table 3 legend

similar levels of total abundance (27 700 individuals $\mathrm{m}^{-2}$ ), no difference between seagrass and bare sand treatment was recorded (Fig. 4a, Table 2). However, in terms of species richness, BS on Day 33 exhibited the highest number of species, thus differing significantly $(\mathrm{p}<0.05)$ from the seagrass treatments (Fig. 4b, Table 2). At this stage, more species were recruited to the Zostera marina units (mean $4.8 \mathrm{spp}$.) than to the Ruppia maritima units (mean 3.7 species), as shown by a significant ( $\mathrm{p}<$ 0.05) treatment effect (morphology) on species richness on Day 33 (Table 2). The Shannon index $\left(H^{\prime}\right)$ correlated with species number throughout the study period, but no significant effects of the main factors (density, morphology) were recorded, except on Day 33 when diversity was significantly higher $(\mathrm{p}<0.05)$ in the $Z$. marina (mean $H^{\prime}=2.0$ ) than in the $R$. maritima treatment (mean $H^{\prime}=1.6$ ). By Day 43, all treatments showed similar abundances $\left(\sim 35000 \mathrm{~m}^{-2}\right)$ and no significant differences among treatments were found (Fig. 4, Table 2). Hence, in terms of total abundance and species richness, the
Table 2. Two-way ANOVA on effects of shoot morphology and shoot density artificial Ruppia maritima and Zostera marina on number of individuals and number of species

\begin{tabular}{|c|c|c|c|c|c|}
\hline \multirow{2}{*}{ Source of variation } & \multicolumn{3}{|c|}{ No. of individuals } & \multicolumn{2}{|c|}{ No. of species } \\
\hline & df & $F$ & Significance & $F$ & Significance \\
\hline \multicolumn{6}{|l|}{ Day 21} \\
\hline Bare vs vegetated & 1 & 0.38 & ns & 0.06 & ns \\
\hline Morphology (M) & 1 & 0.99 & ns & 1.66 & ns \\
\hline Density (D) & 2 & 2.0 & ns & 2.36 & ns \\
\hline $\mathrm{M} \times \mathrm{D}$ & 2 & 2.73 & ns & 2.83 & ns \\
\hline Residual & 28 & & & & \\
\hline \multicolumn{6}{|l|}{ Day 33} \\
\hline Bare vs vegetated & 1 & 0.22 & $\mathrm{~ns}$ & 6.58 & $\mathrm{p}<0.05$ \\
\hline Morphology (M) & 1 & 1.11 & ns & 8.76 & $\mathrm{p}<0.05$ \\
\hline Density (D) & 2 & 10.03 & $\mathrm{p}<0.05$ & 3.91 & ns \\
\hline $\mathrm{M} \times \mathrm{D}$ & 2 & 1.31 & ns & 0.21 & ns \\
\hline Residual & 28 & & & & \\
\hline \multicolumn{6}{|l|}{ Day 43} \\
\hline Bare vs vegetated & 1 & 0.05 & ns & 0.66 & ns \\
\hline Morphology (M) & 1 & 0.25 & ns & 0.85 & ns \\
\hline Density (D) & 2 & 0.56 & ns & 2.86 & ns \\
\hline $\mathrm{M} \times \mathrm{D}$ & 2 & 0.47 & $\mathrm{~ns}$ & 0.22 & $\mathrm{~ns}$ \\
\hline Residual & 28 & & & & \\
\hline \multicolumn{6}{|l|}{ Day 57} \\
\hline Morphology (M) & 1 & 3.83 & ns & 0.45 & ns \\
\hline Density (D) & 2 & 24.9 & $\mathrm{p}<0.01$ & 9.9 & $\mathrm{p}<0.01$ \\
\hline $\mathrm{M} \times \mathrm{D}$ & 1 & 4.43 & $\mathrm{p}<0.05$ & 0.09 & $\mathrm{~ns}$ \\
\hline Residual & 20 & & & & \\
\hline
\end{tabular}



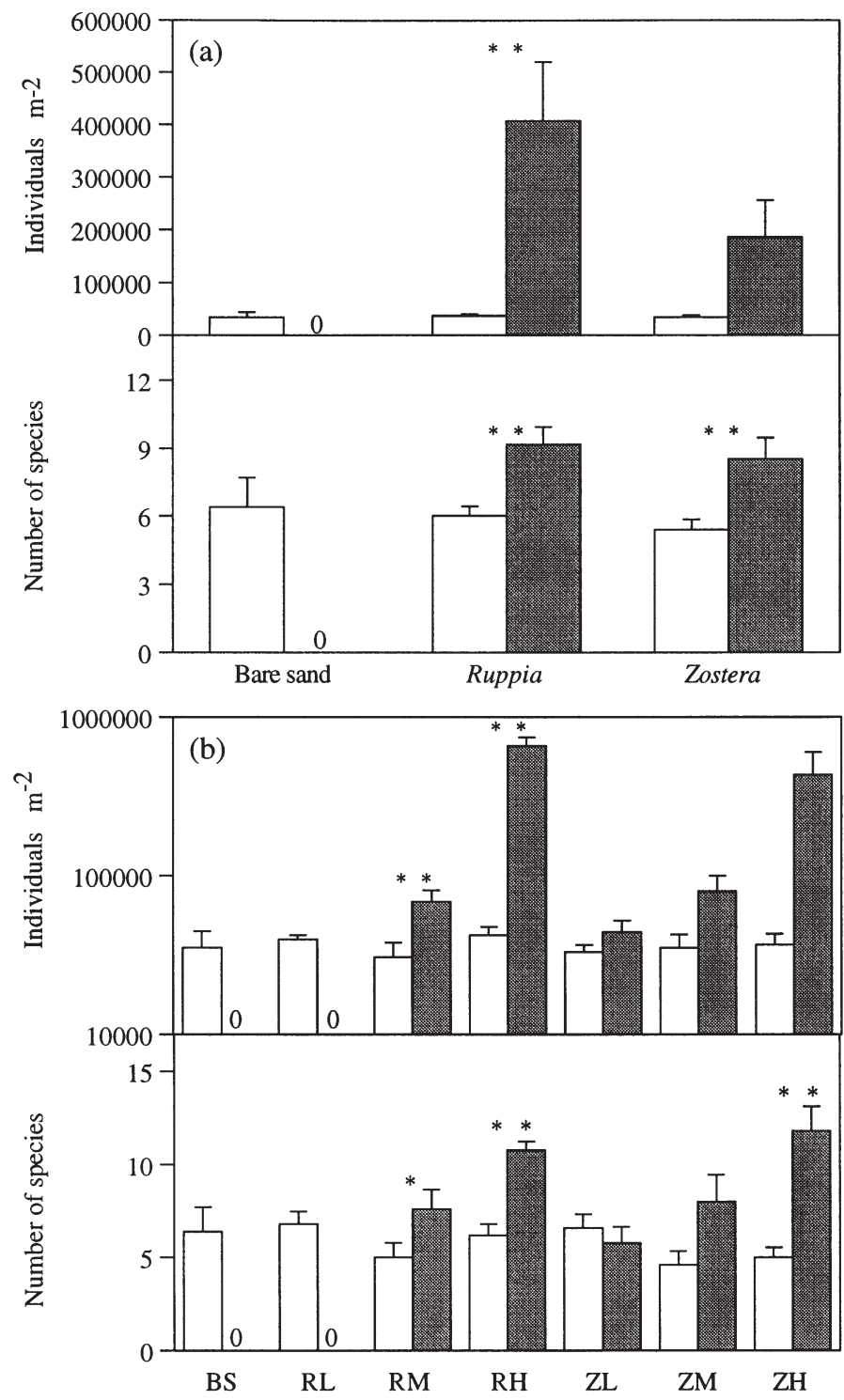

Fig. 5. Community responses to disturbance by strong winds. Total abundance and species richness in bare sand (control) and in artificial Ruppia maritima and Zostera marina (a), and in individual treatments (b). Open bars represent Day 43 (before wind disturbance); shaded bars represent Day 57 (after wind disturbance). Asterisks: significant results (Student's $t$-test for paired samples) $\left({ }^{* *} p<0.01 ;{ }^{*} p<0.05\right)$. For treatment abbreviations see Table 3 legend

starting point for both vegetated and bare units 2 wk prior to wind disturbance was roughly the same (Fig. 4).

The strong winds increased variability within and between treatments and caused a significant increase in total abundance and species richness in the seagrass treatments. Because of sediment loss, the BS and RL communities crashed, while the more complex seagrass units showed an increase in abundance and species richness (Figs. 4 \& 5). In addition to a significant
( $p<0.01$ ) effect of shoot density on total faunal abundance, a significant $(\mathrm{p}<0.05)$ interaction between both main factors was recorded (Table 2), demonstrating that the effect of shoot density on total abundance depended on shoot morphology. Thus, the total number of individuals in RH was 740000 compared to 430000 individuals $\mathrm{m}^{-2}$ in $\mathrm{ZH}$ (Fig. 4a) mainly due to the high abundance of mud snails Hydrobia spp. Shoot density also had a significant effect on species richness (high $>$ medium and low, p < 0.05), but this effect was independent of shoot morphology (Table 2). After wind disturbance, all high- and moderate-density treatments increased in diversity $\left(H^{\prime}\right)$, except RH which clearly decreased because of the high dominance $(85 \%)$ of mudsnails.

\section{Similarity between treatments}

The similarity analysis grouped the infaunal samples according to the successional pattern over time rather than by treatment effects, i.e. seagrass density or morphology (Fig. 6). Even though rare species were included in this analysis, the numerically dominating taxa (Nematoda, Copepoda, Chironomidae and $P y-$ gospio elegans) explained generally $>60 \%$ of the faunal similarities among treatments. During early succession, BS1 clearly differed from the other treatments due to the absence of the tube-building polychaete

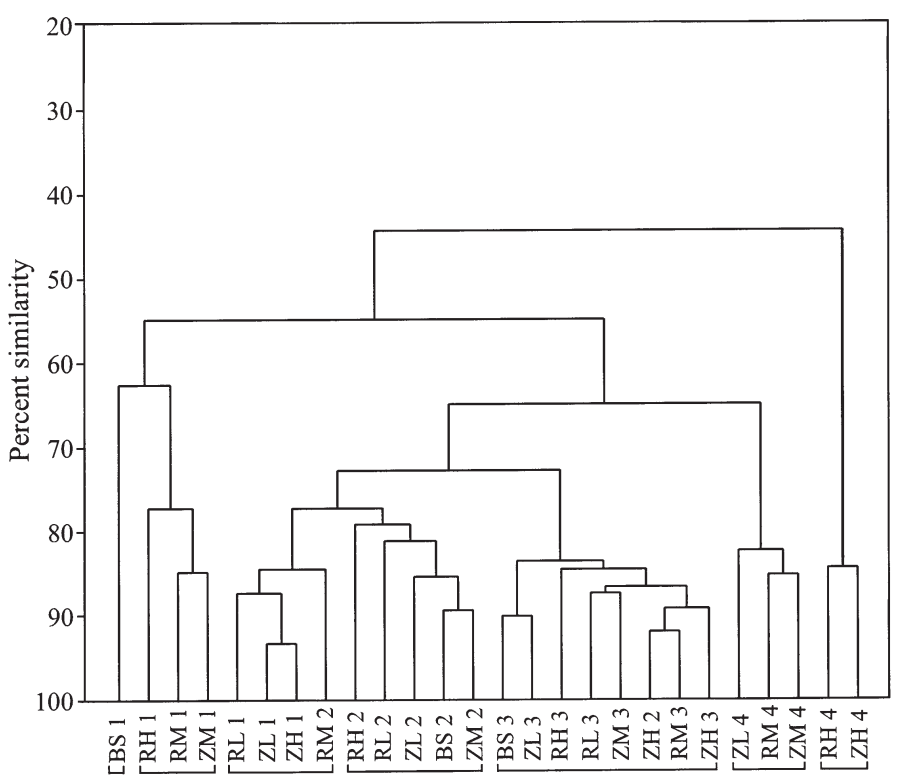

Fig. 6. Bray-Curtis similarity cluster based on all individuals in infaunal samples of the 7 treatments during study period (stress $=$ 0.06). The 4 sampling occasions are indicated by numbers (1 to 4 ) above treatment names on $x$-axis. For treatment abbreviations see Table 3 legend 
P. elegans and to the presence of early colonizers such as ostracods, the amphipod Bathyporeia pilosa and juvenile (500 to $3000 \mu \mathrm{m}$ ) blue mussels Mytilus edulis. Because of low abundance and species richness in $\mathrm{RH}$, RM and ZM on Day 21, these treatments formed a cluster with $>55 \%$ dissimilarity to the remaining seagrass treatments from this date. After wind disturbance, $\mathrm{RH}$ and $\mathrm{ZH}$ peaked in abundance and species number, which gave a separate cluster with low $(<45 \%)$ similarity to all other treatments.

\section{Species-specific responses to habitat complexity and wind disturbance}

Species-specific colonization patterns and the response of the dominating species/taxa to wind disturbance are summarized in Figs. 7 \& 8, respectively. After wind disturbance, almost all of the 6 numerically dominating species examined increased in abundance in both Ruppia maritima and Zostera marina while the bare sand treatment crashed, i.e. all fauna and sedi-
Fig. 7. Colonization patterns (number of individuals $\mathrm{m}^{-2}$ ) of the 6 most common species/taxa in the experimental seagrass units. Timing of disturbance by strong winds is indicated by arrow on $x$-axis. For treatment abbreviations see Table 3 legend

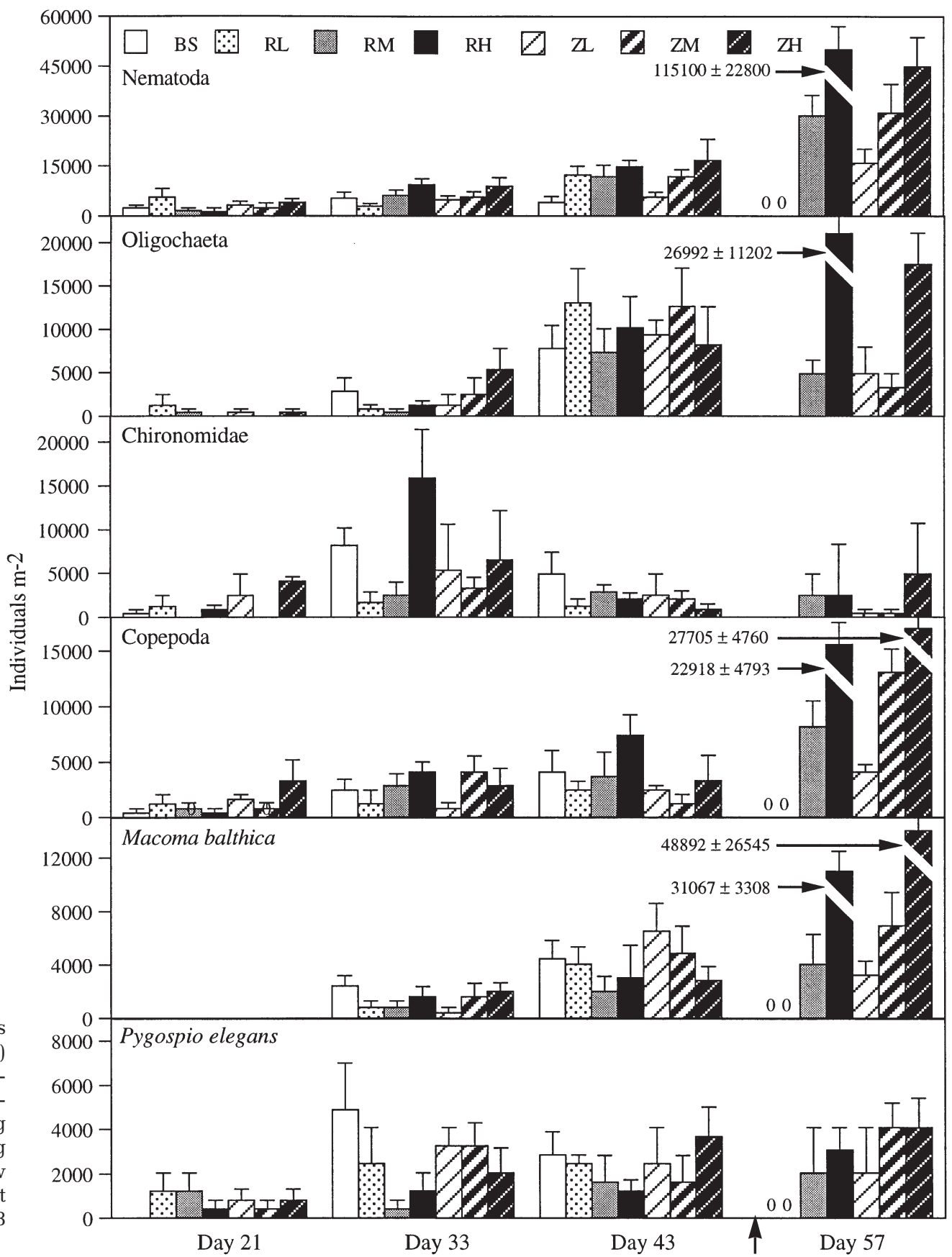




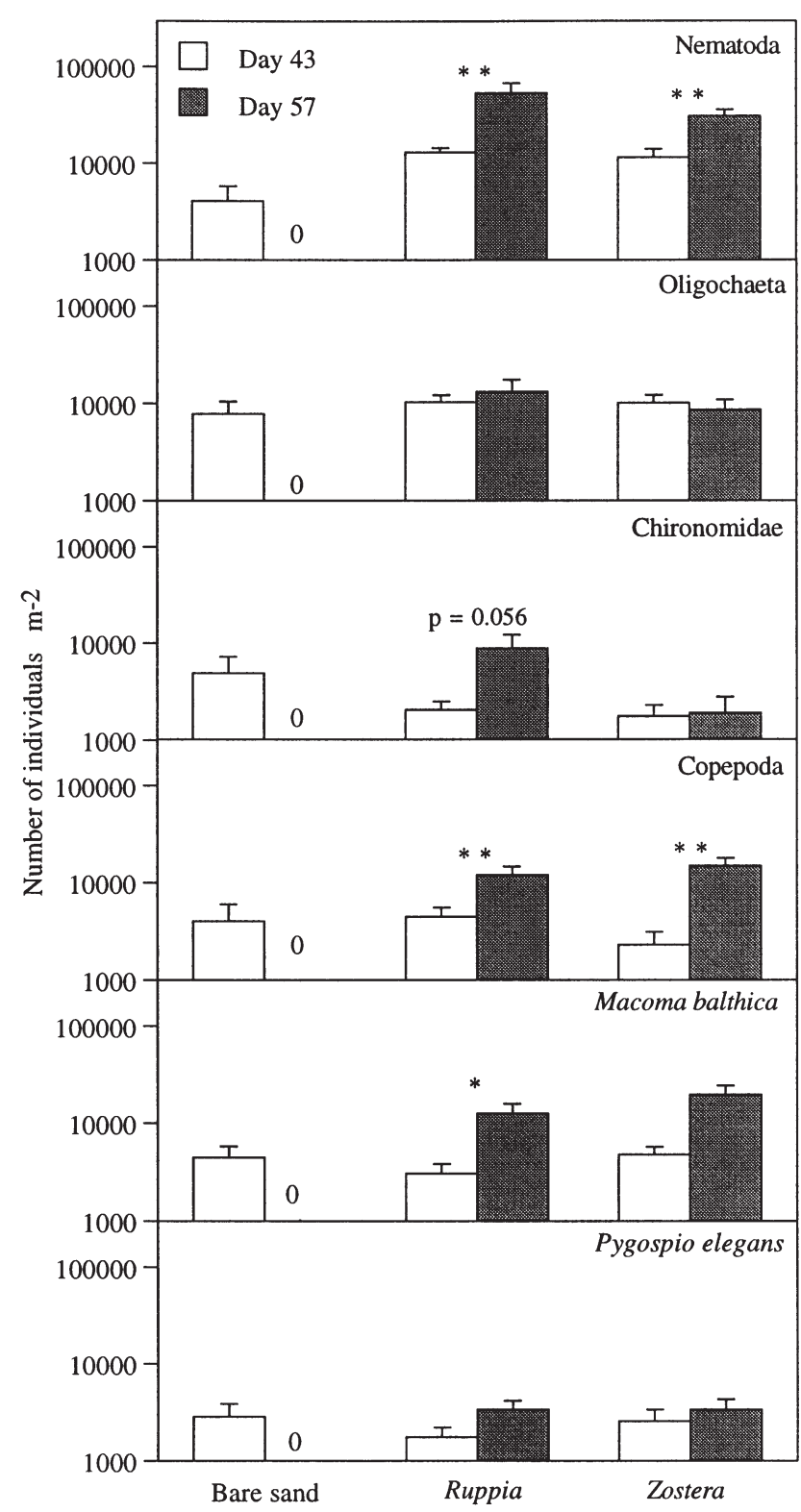

Fig. 8. Species-specific responses to disturbance by strong winds in sand (control) and in artificial Ruppia maritima and Zostera marina. Open bars: Day 43 (before wind disturbance); shaded bars: Day 57 (after wind disturbance). Asterisks: significant differences (Student's $t$-test for paired samples) $\left({ }^{* *} \mathrm{p}<0.01,{ }^{*} \mathrm{p}<0.05\right)$. Difference between Days 43 and 57 for Chironomidae in $R$. maritima is marginally non-significant $(\mathrm{p}=0.056)$

ment were resuspended (Fig. 8). The seagrass units with the highest shoot density contained most species. Thus, over the 2 mo study period, RH and ZH scored 18 and 22 species respectively, while the total recorded for the less-complex treatments (BS included) was 14 to 17 species (Table 3 ). More specifically, mobile, phytal species strictly associated with seagrass (vegetation specialists) at the study site, showed a clear preference for structural above-ground complexity and were exclusively recorded in the moderate- or high-density seagrass treatments. An even larger group of animals (generalists) exhibited no particular preference. Consequently, these species were found in all treatments regardless of complexity. The remaining taxa showed no specific habitat preferences and occurred more or less randomly in all treatments (Table 3 ).

\section{Molluscs, crustaceans and fishes}

The proportion of molluscs increased greatly after wind disturbance, especially in the high-density seagrass treatments. Specifically, juvenile bivalves (Mytilus edulis: 375 to $550 \mu \mathrm{m}$, Cerastoderma glaucum: 250 to $1500 \mu \mathrm{m}$ ) and hydrobid snails ( 425 to $475 \mu \mathrm{m}$ ) which before wind disturbance were nearly absent from all treatments, contributed to the high numbers of molluscs recorded on Day 57. Also Theodoxus fluviatilis and Limapontia capitata were gained by complexity and disturbance, and peaked on Day 57 in RH and ZH (Table 3). From Day 33 onwards, juvenile Macoma balthica occurred in all treatments in densities of $<6000$ individuals $\mathrm{m}^{-2}$, but peaked in abundance after wind disturbance only in $\mathrm{RH}$ and $\mathrm{ZH}$ (Fig. 7). On Day 43 , the 2 smallest size classes previously recorded in Ruppia maritima and sand were absent, and the size distribution of $M$. balthica was similar in all treatments (mean length: $475 \mu \mathrm{m}$ ) but significantly (paired $t$-test: $\mathrm{p}<0.0001$ ) smaller than on Day 57 (mean length:

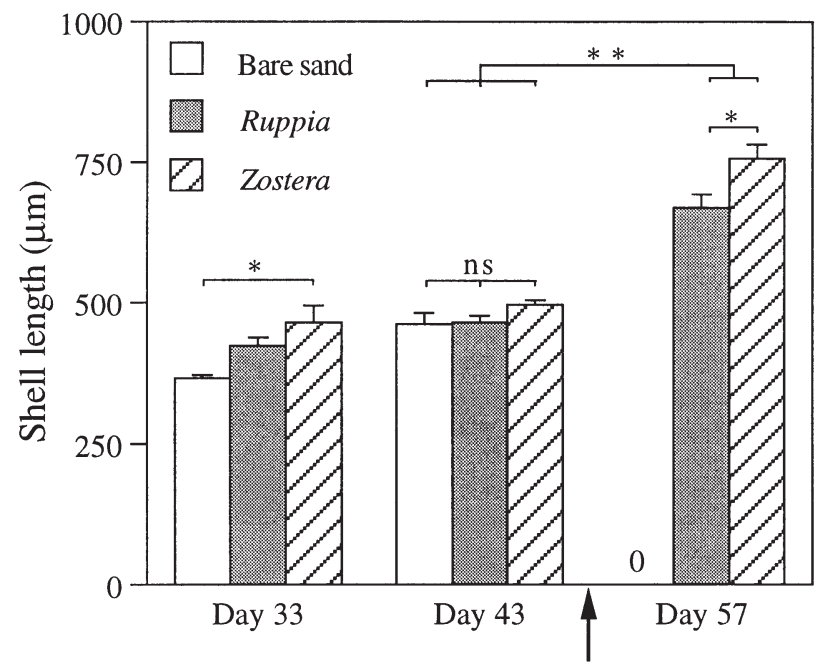

Fig. 9. Mean shell length of juvenile Macoma balthica in sand (control) and in artificial Ruppia maritima and Zostera marina. Settling size of pelagic $M$. balthica larvae in study area is $\geq 250 \mu \mathrm{m}$, size of newly settled individuals is 300 to $350 \mu \mathrm{m}$ (Bonsdorff et al. 1995). Timing of wind disturbance is indicated by arrow on $x$-axis. Asterisks: significant results (unpaired Student's $t$-tests) $\left({ }^{* *} \mathrm{p}<0.01,{ }^{*} \mathrm{p}<0.05 ; \mathrm{ns}=\right.$ not significant) 
Table 3. Species/taxa recorded in artificial seagrass units 4 June to 31 July 1997. \%: average percentage frequency of occurrence in all samples during study period; Rank: species rank based on percentage occurrence; Occ.: occurrence $(\mathrm{C}=\mathrm{common}, \mathrm{O}=$ occasional, $\mathrm{R}=$ rare); Mob.: mobility $(\mathrm{M}=$ mobile, $\mathrm{S}=$ sedentary); Lar.: larvae $(\mathrm{B}=$ benthic, $\mathrm{P}=$ pelagic, $\mathrm{D}=$ direct development); nr: not recorded. BS: bare sand (control); RL, RM, RH, low-, medium-, high-density Ruppia maritima, respectively; ZL, ZM, ZH, low-, medium-, high-density Zostera marina, respectively

\begin{tabular}{|c|c|c|c|c|c|c|c|c|c|c|c|c|}
\hline Taxon & BS & RL & RM & RH & ZL & $\mathrm{ZM}$ & $\mathrm{ZH}$ & $\%$ & Rank & Occ. & Mob. & Lar. \\
\hline Turbellaria & + & - & + & + & + & + & + & 17.5 & 7 & $\mathrm{O}$ & M & B \\
\hline \multicolumn{13}{|l|}{ Nemertinea } \\
\hline Prostoma obscurum & - & - & + & - & - & + & + & 4.3 & 13 & $\mathrm{R}$ & $\mathrm{M}$ & B \\
\hline Nematoda & + & + & + & + & + & + & + & 88.5 & 1 & $\mathrm{C}$ & $\mathrm{S}$ & $\mathrm{B}$ \\
\hline \multicolumn{13}{|l|}{ Polychaeta } \\
\hline Pygospio elegans & + & + & + & + & + & + & + & 51.4 & 5 & $\mathrm{C}$ & $\mathrm{S}$ & $\mathrm{P}$ \\
\hline Marenzelleria viridis & + & - & - & - & - & - & + & 1.4 & 18 & $\mathrm{R}$ & M & $\mathrm{P}$ \\
\hline Nereis diversicolor & - & - & - & - & - & + & + & 3.6 & 15 & $\mathrm{R}$ & M & $\mathrm{P}$ \\
\hline Oligochaeta & + & + & + & + & + & + & + & 55.1 & 3 & $\mathrm{C}$ & $\mathrm{S}$ & B \\
\hline \multicolumn{13}{|l|}{ Mollusca } \\
\hline Theodoxus fluviatilis & + & + & + & + & + & - & + & 11.6 & 11 & $\mathrm{O}$ & M & B \\
\hline Hydrobia spp. & - & - & + & + & + & + & + & 15.4 & 8 & $\mathrm{O}$ & M & $\mathrm{P}$ \\
\hline Limapontia capitata & - & - & - & + & - & - & + & 1.6 & 17 & $\mathrm{R}$ & $\mathrm{M}$ & B \\
\hline Mytilus edulis & + & - & + & + & + & - & + & 13.8 & 9 & $\mathrm{O}$ & $\mathrm{S}$ & $\mathrm{P}$ \\
\hline Cerastoderma glaucum & + & + & + & + & + & + & + & 12.3 & 10 & $\mathrm{O}$ & $\mathrm{S}$ & $\mathrm{P}$ \\
\hline Macoma balthica & + & + & + & + & + & + & + & 50.4 & 4 & $\mathrm{C}$ & $\mathrm{S}$ & $\mathrm{P}$ \\
\hline \multicolumn{13}{|l|}{ Crustacea } \\
\hline Crangon crangon $^{\mathrm{a}}$ & - & + & - & - & - & - & - & $\mathrm{nr}$ & $\mathrm{nr}$ & $\mathrm{R}$ & $\mathrm{M}$ & - \\
\hline Gammarus spp. & - & - & + & + & - & - & + & 3.75 & 14 & $\mathrm{R}$ & M & $\mathrm{D}$ \\
\hline Bathyporeia pilosa & + & + & + & + & + & + & + & 19.2 & 6 & $\mathrm{O}$ & M & $\mathrm{D}$ \\
\hline Saduria entomon & - & - & - & + & + & - & + & 2.3 & 16 & $\mathrm{R}$ & M & $\mathrm{D}$ \\
\hline Idotea baltica & - & - & - & - & - & - & + & 0.7 & 19 & $\mathrm{R}$ & M & $\mathrm{D}$ \\
\hline Copepoda & + & + & + & + & + & + & + & 68.4 & 2 & $\mathrm{C}$ & M & $\mathrm{B}$ \\
\hline Ostracoda & + & + & - & + & - & + & + & 11.3 & 12 & $\mathrm{O}$ & M & $\mathrm{B}$ \\
\hline Mycidacea $^{a}$ & - & + & - & - & - & - & - & $\mathrm{nr}$ & $\mathrm{nr}$ & $\mathrm{R}$ & M & - \\
\hline \multicolumn{13}{|l|}{ Insecta } \\
\hline Chironomidae & + & + & + & + & + & + & + & 51.4 & 5 & $\mathrm{C}$ & $\mathrm{S}$ & $\mathrm{B}$ \\
\hline \multicolumn{13}{|l|}{ Pisces } \\
\hline Pomatoschistus minutus & + & + & - & + & - & - & - & $\mathrm{nr}$ & $\mathrm{nr}$ & $\mathrm{O}$ & M & - \\
\hline Zoarces viviparus ${ }^{\mathrm{a}}$ & - & + & - & - & - & - & - & $\mathrm{nr}$ & $\mathrm{nr}$ & $\mathrm{R}$ & $\mathrm{M}$ & - \\
\hline Nerophis ophidion $^{\mathrm{a}}$ & - & - & + & + & + & + & + & $\mathrm{nr}$ & $\mathrm{nr}$ & $\mathrm{C}$ & M & - \\
\hline Pungitius pungitius $^{\mathrm{a}}$ & - & + & + & - & - & - & + & $\mathrm{nr}$ & $\mathrm{nr}$ & $\mathrm{O}$ & M & - \\
\hline Total & 14 & 15 & 16 & 18 & 14 & 14 & 22 & & & & & \\
\hline
\end{tabular}

$712 \mu \mathrm{m})$. Thus, the strong winds resulted in a size distribution skewed towards larger individuals in Zostera marina compared to $R$. maritima (unpaired $t$-test: $\mathrm{p}=0.0212$ ), and the total absence of the smaller size class $(475 \mu \mathrm{m})$ that had dominated all treatments on Day 43 (Fig. 9).

Harpacticoid copepods were common before wind disturbance but usually occurred in densities of $<5000$ individuals $\mathrm{m}^{-2}$. On Day 57 this group peaked in $\mathrm{ZH}$ (27000 individuals $\mathrm{m}^{-2}$ ) and RH $\left(23000 \mathrm{~m}^{-2}\right)$ (Fig. 7), a pattern similar to that of ostracods. In contrast, the sand-dwelling amphipod Bathyporeia pilosa seemed unaffected by disturbance and reached its highest densities (800 to 1700 individuals $\mathrm{m}^{-2}$ ) in bare sand. After wind disturbance, this amphipod was present in the seagrass treatments in densities similar to those before disturbance. After wind disturbance, the isopods
Saduria entomon and Idotea baltica were recorded exclusively in the high-density seagrass treatments.

Epibenthic fishes were commonly found ( $\mathrm{n}=36$ recordings) in the artificial seagrass units (Table 3), and discriminated between seagrass densities and morphologies. Sand gobies were only found in bare sand (BS) or in the Ruppia maritima treatments (RL, $\mathrm{RH})$, while $90 \%$ of all observations on pipefish were made in the Zostera marina treatments ( $\mathrm{ZM}, \mathrm{ZH})$. Sticklebacks Pungitius pungitius were far less common (3 recordings) and were observed only on Days 33 and 43 in both $R$. maritima (RL, RM) and Z. marina $\left(\mathrm{ZH}_{i}\right.$ 1 nest-building male). Eelpout Zoarces viviparus, although commonly associated with vegetation and drifting algae at the study site (Boström pers. obs.), was rare in the experimental units and the only specimen was observed in RL. 


\section{DISCUSSION}

\section{Trapping of algae and sediment}

In contrast to a field study by Bell et al. (1995), our experiment demonstrated positive, but species-specific relationships between shoot density of Ruppia maritima and Zostera marina and accumulation of drifting algae. Hence, both high-density seagrass units $(\mathrm{RH}$, $\mathrm{ZH})$ trapped most algae. The average algal cover in R. maritima was also $20 \%$ higher than in Z. marina, demonstrating a marked effect of shoot morphology on algal accumulation patterns (Fig. 3a). Since the artificial Z. marina shoots were 3 times longer, with a leaf area 12 times larger than the artificial $R$. maritima shoots (Table 1), this probably prevented entrance of algae into the $Z$. marina units. After wind disturbance, the amount of sediment increased in the most complex treatments $(\mathrm{RH}, \mathrm{ZH})$, demonstrating density-dependent effects of both types of seagrass mimics on processes such as current-baffling, particle-trapping and sediment-binding, but also suggesting minimal possibility of infaunal dislodgement from experimental or natural seagrass patches with high shoot density. Similarily, Eckman (1983) demonstrated higher accumulation of sediment particles and drifting filamentous algae in artificial medium and high-density (625 and 2500 straws $\mathrm{m}^{-2}$ respectively) vegetation patches (Scirpus americanus mimics) compared to low-density (156 straws $\mathrm{m}^{-2}$ ) patches.

\section{Faunal-source pools and ways of transport}

At the study site, the ambient habitats support populations of all species recorded in the artificial seagrass units (Fig. 2). The Zostera marina infauna is dominated by chironomid larvae (8000 individuals $\mathrm{m}^{-2}$ ) a group found in high densities (15000 individuals $\mathrm{m}^{-2}$ ) also in the natural Ruppia maritima patches, and both seagrass habitats are important for juvenile bivalves (see 'Materials and methods: Study area'). The Z. marina leaf fauna is totally dominated by crustaceans; gammarid amphipods, copepods, ostracods and Idotea baltica being the numerically most important taxa (Boström unpubl. data). Drifting algae constitute an additional short-term phytal habitat (sensu Holmquist 1997), harbouring high densities of invertebrates (1600 individuals $\mathrm{g}^{-1}$ algal dry wt, $\mathrm{n}=5$ ). The faunal composition of these mats in July 1997 was dominated by chironomid larvae, gammarid amphipods, copepods and juvenile bivalves (Cerastoderma glaucum and Macoma balthica).

What is the importance of these animal source pools for the colonization and animal composition of the arti- ficial seagrass units? Given that interactions between source pools and experimental units occurred, at least 4 colonization routes are possible: (1) pelagic settlement, (2) resuspension, (3) active swimming, or (4) passive rafting by means of drifting algae. The 3 latter colonization modes includes interactions with surrounding phytal habitats, bare sand, or neighbouring experimental seagrass units. In addition, reproduction within the seagrass units (e.g. oligochaetes, Norkko \& Bonsdorff 1996) or lower predation pressure in combination with more food (organic matter) for infauna in the high-density units may underlie the colonization patterns we observed.

Primary settlement from the plankton into the experimental units was unlikely to have occurred, since the animals we found were almost exclusively juvenile stages of settled (redistributed) macrofauna (e.g. Macoma balthica: Fig. 9), and only about $30 \%$ of the species sampled disperse/reproduce via pelagic larvae (Table 3). Compared to fully marine environments, where planktotrophic larval development dominates (Pechenik 1999), the low proportion of pelagically reproducing zoobenthic species in the Baltic Sea and the patchy, low-density character of Baltic seagrass beds (Boström \& Bonsdorff 1997) may have consequences for spatial recruitment patterns. This includes a more significant role of post-settlement events (Bonsdorff et al. 1995) such as resuspension from ambient sediments or transport between seagrass patches by active swimming or passive rafting via drifting algae (Holmquist 1997, Norkko et al. 2000). Because of the lack of predatory crabs and a diminished role of seagrass associated predatory fish in this area (Boström \& Mattila 1999), active dispersal of animals both within seagrass sites and between algal belts and seagrass meadows is possibly less risky than in fully marine environments. However, as eelgrass meadows in the northern Baltic Sea occur almost solely on exposed sandy bottoms (Boström \& Bonsdorff 1997), stochastic wind-driven disturbance events are likely to play a more important role in the spatial distribution of newly settled fauna than pelagic or post-settlement predation. Consequently, animal movements in our study area are mostly physically controlled, and only indirectly dependent on biotic factors i.e. by the habitat requirements of Zostera marina.

At our site, drifting algae may be trapped for several weeks in the bare sand patches within the seagrass (observed by diving and aerial photography 1997). Such accumulations may increase the permeability of seagrass and algal patch boundaries or increase the exchange of animals between isolated seagrass patches within the site (Holmquist 1994, 1998), and enable transport of individuals between sites. Hence, drift algae may have functioned as a transport mechanism for mobile fauna between seagrass and the experimental area (Norkko 
et al. 2000), or as a moving trap for settling and newly settled animals (e.g. bivalves, Bonsdorff et al. 1995).

The surrounding seagrass leaf fauna is dominated by crustaceans with good swimming ability, and such species should exercise active choice of substrate (Palmer 1988). Accordingly, Idotea baltica and Gammarus spp. were found only in the moderate- or high-density artificial seagrass, suggesting that for these animals the artificial seagrass mimics were good simulation of natural seagrass (Boström \& Mattila 1999). Both species are active swimmers (Table 3), and amongst the most common in the surrounding (>30 $\mathrm{m}$ away) seagrass meadows. Virnstein \& Curran (1986) also recorded active amphipod dispersal over bare sand and rapid colonization of isolated artificial seagrass.

However, some amphipods seem to be stationary within seagrass patches. For example Corophium volutator, the most common infaunal amphipod in seagrass at the study site (Fig. 2) was not recorded in the experimental seagrass patches. C. volutator may benefit from the presence of algal mats (Bonsdorff 1992), and in the laboratory, this species is capable of migrating from bare sand to drifting algae (Norkko 1998). However, since C. volutator at this site is totally seagrassdependent, initial migration to bare sand is unlikely. Field studies in other areas (Florida, USA) have also shown greater exchange of invertebrates between drift algae and seagrass than between drift algae and bare sand (Holmquist 1994). Hence, at exposed sites such as ours, C. volutator does not seem to migrate over bare sand to reach distant seagrass patches or drifting algae, although this amphipod is reported to possess a high degree of mobility (e.g. Hughes \& Gerdol 1997, Lawrie \& Raffaelli 1998a,b).

\section{Species-specific colonization features in low- and high-complexity habitats}

Ólafsson et al. (1994) suggested that post-settlement events (e.g. predation) are important on bare sediments, while larval availability may be more important for recruitment to seagrass beds. Accordingly, the coring data from our site suggests that spat survival in bare sand is lower (Fig. 2), probably due to resuspension and redistribution or foraging by flatfish or shrimps (Aarnio 1999). However, our experimental data show that strong winds greatly increased the number of recruits in dense artificial seagrass but not in the less complex treatments, suggesting that postsettlement events are more important than larval supply in explaining enhanced faunal densities in Baltic seagrass habitats.

The response to complexity and disturbance varied between different animal groups. For example, nematodes and the tube-building polychaete Pygospio elegans did not show differences between the Ruppia maritima and Zostera marina treatments. However, nematodes clearly increased in abundance with increasing complexity, especially after disturbance. Consequently, after $2 \mathrm{mo}$, the mean abundance level of this group was far above its mean starting level (Fig. 10). In contrast, on Day 33 the tube-building polychaete $P$. elegans was present in decreasing numbers with increasing complexity, showed no clear response to wind action, and experienced no change in mean population size during the study period (Fig. 10). A dense tube matrix produced by this species probably effectively prevents sediment erosion, as observed among $R$. maritima rhizomes at the study site.

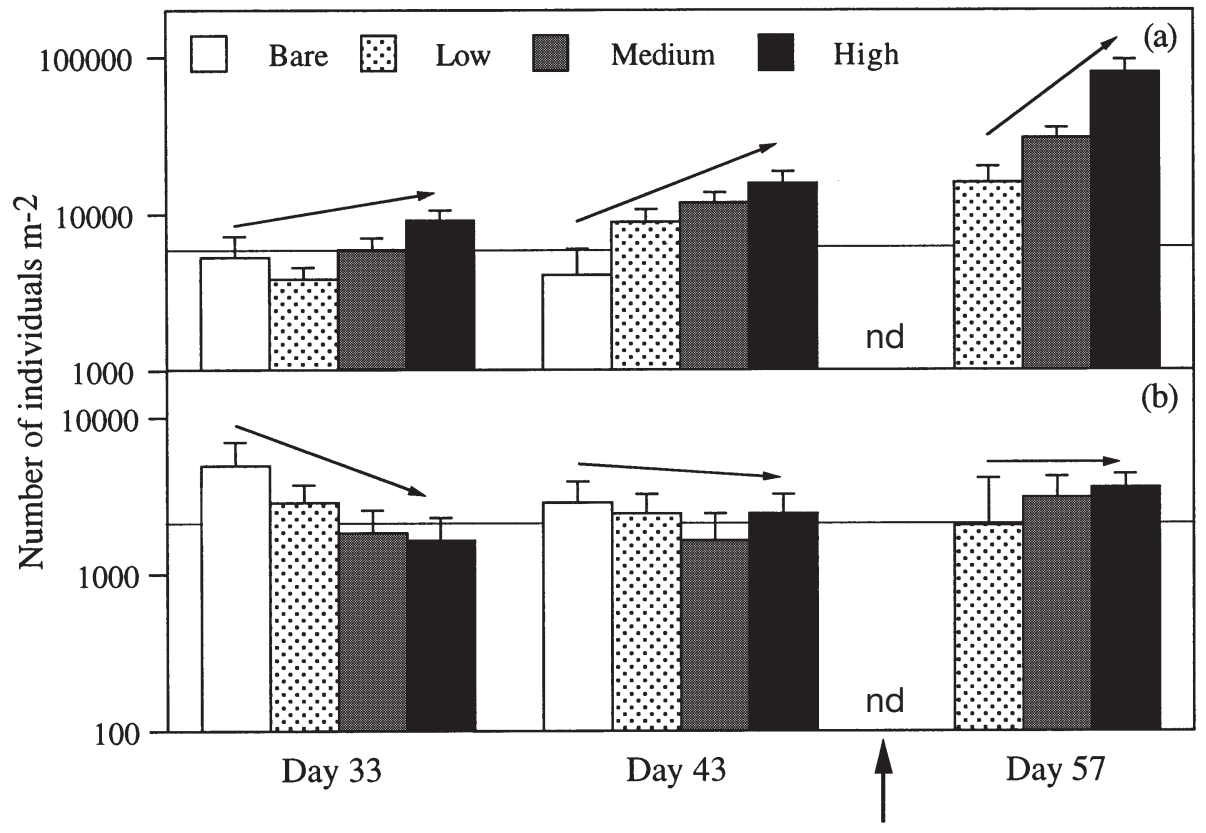

Fig. 10. Colonization patterns of 2 infaunal dominants in relation to habitat complexity (shoot density) and disturbance (strong winds). Artificial Ruppia maritima and Zostera marina treatments with equal densities are pooled into single mean values. (a) Nematoda; (b) tube-building sedentary polychaete Pygospio elegans. Horizontal line represents mean abundance level at Day 33. Timing of wind disturbance is indicated by arrow on $x$-axis; arrows above histograms indicate colonization trends in relation to complexity. Scale is logarithmic. nd = no data 


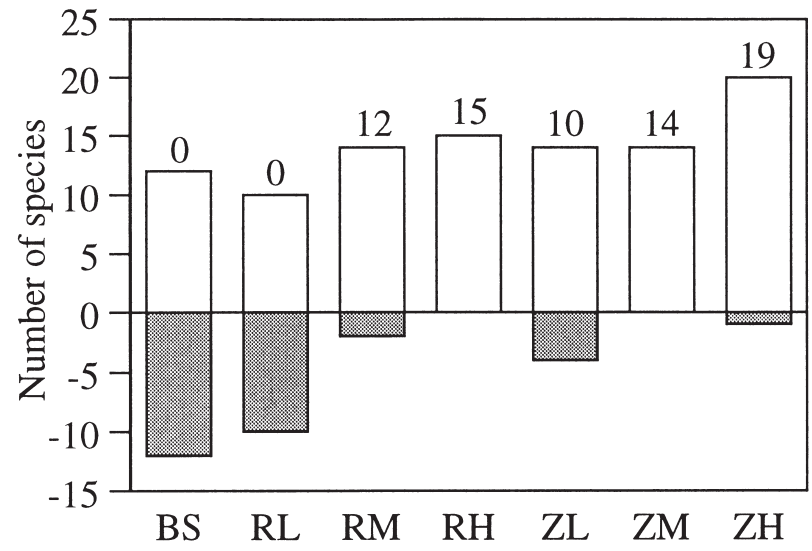

Fig. 11. Species turnover exemplified by species gained (open bars) and lost (shaded bars) in bare sand (BS, control) and in different complexities of artificial Ruppia maritima and Zostera marina during 2 mo colonization experiment. Values above bars: net gain in terms of number of species present at the end of the experiment $(0=$ resuspension of all fauna and sediment, i.e. no sediment left in colonization trays). Abbreviations as in Table 3 legend

All species recruited to the BS and RL treatments during the experiment were also lost or resuspended within the same period, resulting in zero net gain in terms of species number in these treatments (Fig. 11). In the more complex treatments, the loss was less pronounced and clearly compensated by input through recruitment, resulting in a net gain of between 10 and 20 species (Fig. 11). The high-density treatments collected most species. Hence, at the study site, the bare sand fauna experiences short-term colonization (days to weeks) interrupted by stochastic wind-driven disturbance-events, with a subsequent high species turnover and low species richness, while the seagrass meadows are characterized by higher relative stability (weeks to years), accumulation of animals and low species turnover, resulting in higher diversity. Thus, in this system, intermediate disturbance events (Connell 1978) generate within-site heterogenity, i.e. the large-scale mosaic pattern of seagrass patches, and promote animal diversity within patches. Generally, the effects of any disturbance depend on frequency, intensity and timing (Huston 1994), but may also be substrate-dependent (sessile rocky-shore animals: Sousa 1985), as demonstrated in this study by the habitat-complexity-dependent effects of wind disturbance on soft-bottom benthos.

\section{Concluding remarks}

In high-energy environments in the northern Baltic Sea, patches of seagrass are important for faunal recruitment, survival and diversity. The shelter and stability provided by above- and below-ground struc- tures enable existence of diverse faunal assemblages in otherwise species-poor sandy sediments. Our field data and experiment showed that seagrasses with differing morphology can provide similar ecological functions. Wind-mediated disturbance (a common phenomenon at Baltic Zostera marina sites) may create and maintain high animal abundance and diversity in medium- and high-density seagrass both directly through resuspension or indirectly through accumulation of animals in drifting algae. However, caution should be used in extrapolating the spatial and temporal faunal patterns observed in this experiment to sites with differing physical settings and configuration, and for structure and species composition of seagrass patches. Conservation of seagrass meadows in adequate densities is crucial to maintaining important species functions in the Baltic ecosystems. Loss of a functional group, or drastic reduction of a structuring species such as Ruppia maritima or Z. marina, will reduce species diversity and change ecosystem functions (Elmgren \& Hill 1997, Bonsdorff \& Pearson 1999). At the site described here, such alterations would cause an abrupt change in seagrass community organization, stability and diversity evolved over the long term, i.e. the past millenium (Reusch et al. 1999), and result in a simpler benthic ecosystem favoring species tolerant to exposure or phytal taxa able to successfully utilize unstable habitats such as mats of decaying algae.

Acknowledgements. We thank the staff and students at Husö Biological Station for help with the field work. We are grateful to J. Mattila, A. Norkko, J. Norkko and M. Tallqvist for help with the diving. Walter G. Nelson gave valuable comments on the experimental design. Patrik Kraufvelin kindly assisted with the multivariate analysis. This study was financially supported by the Academy of Finland (Project 38021).

\section{LITERATURE CITED}

Aarnio K (1999) Experimental evidence of predation by juvenile flounder, Platichtys flesus, on a shallow water meiobenthic community. J Exp Mar Biol Ecol 246:125-138

Aarnio K, Bonsdorff E (1993) Seasonal variation in abundance and diet of the sand goby, Pomatoschistus minutus (Pallas), in a northern Baltic archipelago. Ophelia 37:19-30

Aarnio K, Bonsdorff E, Rosenback N (1996) Food and feeding habits of juvenile flounder, Platichtys flesus (L.), and turbot, Scophthalamus maximus L., in the Åland archipelago, northern Baltic Sea. J Sea Res 36:311-320

Bell SS, Hicks GRF (1991) Marine landscapes and faunal recruitment: a field test with seagrasses and copepods. Mar Ecol Prog Ser 73:61-68

Bell JD, Westoby M (1986a) Importance of local changes in leaf height and density to fish and decapods associated with seagrasses. J Exp Mar Biol Ecol 104:249-274

Bell JD, Westoby M (1986b) Variation in seagrass height and density over a wide spatial scale: effects on common fish and decapods. J Exp Mar Biol Ecol 104:275-295 
Bell JD, Westoby M, Steffe AS (1987) Fish larvae settling in seagrass: do they discriminate between beds of different leaf density? J Exp Mar Biol Ecol 1987:133-144

Bell SS, Hall, MO, Robbins BD (1995) Toward a landscape approach in seagrass beds: using macrofaunal accumulation to address questions of scale. Oecologia 104:163-168

Bonsdorff E (1992) Drifting algae and zoobenthos - effects on settling and community structure. Neth J Sea Res 30:57-62

Bonsdorff E, Pearson TH (1999) Variation in the sublittoral macrozoobenthos of the Baltic Sea along environmental gradients: a functional-group approach. Aust J Ecol 24: 312-326

Bonsdorff E, Norkko A, Boström C (1995) Recruitment and population maintenance of the bivalve Macoma balthica (L.) - factors affecting settling success and early survival on shallow sandy bottoms. In: Eleftherion A, Ansell AD, Smith CJ (eds) Proc 28th Eur Mar Biol Symp. Olsen \& Olsen, Fredensborg, p 253-260

Boström C, Bonsdorff E (1997) Community structure and spatial variation of benthic invertebrates associated with Zostera marina (L.) beds in SW Finland. J Sea Res 37:153-166

Boström C, Mattila J (1999) The relative importance of food and shelter for seagrass associated invertebrates: a latitudinal comparison of habitat choice by isopod grazers. Oecologia 120:162-170

Connell JH (1978) Diversity in tropical rain forests and coral reefs. Science 199:1302-1310

Cummings E, Ruber E (1987) Copepod colonization of natural and artificial substrates in a salt marsh pool. Estuar Coast Shelf Sci 25:637-645

Eckman JE (1983) Hydrodynamic processes affecting benthic recruitment. Limnol Oceanogr 28:241-257

Eckman JE (1987) The role of hydrodynamics in recruitment, growth, and survival of Argopecten irradians (L.) and Anomia simplex (D'Orbigny) within eelgrass meadows J Exp Mar Biol Ecol 106:165-191

Eggleston DB, Elis WE, Etherington LL, Dahlgren CP, Posey $\mathrm{MH}$ (1999) Organism responses to habitat fragmentation and diversity: habitat colonization by estuarine macrofauna. J Exp Mar Biol Ecol 236:107-132

Elmgren R, Hill C (1997) Ecosystem function at low biodiversity - the Baltic example. In: Ormond RFG, Gage JD, Angel MV (eds) Marine biodiversity — patterns and processes. Cambridge University Press, Cambridge, p 319-336

Fonseca MS, Fisher JS (1986) A comparison of canopy friction and sediment movement between four species of seagrass with reference to their ecology and restoration. Mar Ecol Prog Ser 29:15-22

Granö O, Roto M (1991) Egentliga Finlands havsstränder. Åbo Universitet, Åbo, Finland Skärgårdens utvecklingsprojekt

Grizzle RE, Short FT, Newell CR, Hoven H, Kindblom L (1996) Hydrodynamically induced synchronous waving of seagrasses: 'monami' and its possible effects on larval mussel settlement. J Exp Mar Biol Ecol 206:165-177

Guerrini A, Colangelo MA, Ceccherelli VU (1998) Recolonization patterns of meiobenthic communities in brackish vegetated and unvegetated habitats after induced hypoxia/anoxia. Hydrobiologia 375/376:73-87

Hicks GRF (1989) Does epibenthic structure negatively affect meiofauna? J Exp Mar Biol Ecol 133:39-55

Holmquist JG (1994) Benthic macroalgae as a dispersal mechanism for fauna: influence of a marine tumbleweed. J Exp Mar Biol Ecol 180:235-251

Holmquist JG (1997) Disturbance and gap formation in a marine benthic mosaic: influence of shifting macroalgal patches on seagrass structure and mobile invertebrates. Mar Ecol Prog Ser 158:121-130
Holmquist JG (1998) Permeability of patch boundaries to benthic invertebrates: influences of boundary contrast, light level, and faunal density and mobility. Oikos 81: 558-566

Horinouchi M, Mitsuhiko S (1999) Effects of changes in seagrass shoot density and leaf height on abundances and distribution patterns of juveniles of three gobiid fishes in a Zostera marina bed. Mar Ecol Prog Ser 183:87-94

Hughes RG, Gerdol V (1997) Factors affecting the distribution of the amphiod Corophium volutator in two estuaries in south-east England. Estuar Coast Shelf Sci 44:621-627

Huston MA (1994) Biological diversity - the coexistence of species on changing landscapes. Cambridge University Press, Cambridge

Jenkins GP, Sutherland CR (1997) The influence of habitat structure on nearshore fish assemblages in a southern Australian embayment: colonisation and turnover rate of fishes associated with artificial macrophyte beds of varying physical structure. J Exp Mar Biol Ecol 218:103-125

Lawrie SM, Raffaelli DG (1998a) Activity and mobility of Corophium volutator: a field study. Mar Freshw Behav Physiol 31:39-53

Lawrie SM, Raffaelli DG (1998b) In situ swimming behaviour of the amphipod Corophium volutator (Pallas). J Exp Mar Biol Ecol 224:237-251

Norkko A (1998) The impact of loose-lying algal mats and predation by the brown shrimp Crangon crangon (L.) on infaunal prey dispersal and survival. J Exp Mar Biol Ecol 221:99-116

Norkko A, Bonsdorff E (1996) Population responses of coastal zoobenthos to stress induced by drifting algal mats. Mar Ecol Prog Ser 140:141-151

Norkko J, Bonsdorff E, Norkko A (2000) Drifting algal mats as an alternative habitat for benthic invertebrates: species specific responses to a transient resource. J Exp Mar Biol Ecol 248:79-104

Ólafsson EB, Peterson CH, Ambrose WG (1994) Does recruitment limitation structure populations and communities of macro-invertebrates in marine soft sediments: the relative significance of pre- and post-settlement processes. Oceanogr Mar Biol Annu Rev 32:65-109

Orth RJ (1992) A perspective on plant-animal interactions in seagrasses: physical and biological determinants influencing plant and animal abundance. In: John DM, Hawkins SJ, Price JH (eds) Plant-animal interactions in the marine benthos. Systematics Association Clarendon, Oxford, p 147-164 (Spec Vol No. 46)

Palmer MA (1986) Hydrodynamics and structure: interactive effects on meiofauna dispersal. J Exp Mar Biol Ecol 104: 53-68

Palmer MA (1988) Dispersal of marine meiofauna: a review and conceptual model explaining passive transport and active emergence with implications for recruitment. Mar Ecol Prog Ser 48:81-91

Pechenik JA (1999) On the advantages and disadvantages of larval stages in benthic marine invertebrate life cycles. Mar Ecol Prog Ser 177:269-297

Petersen JE, Cornwell JC, Kemp WM (1999) Implicit scaling in the design of experimental aquatic ecosystems. Oikos 85:3-18

Peterson CH (1986) Enhancement of Mercenaria mercenaria densities in seagrass beds: is pattern fixed during settlement season or altered by subsequent differential survival? Limnol Oceanogr 31:200-205

Reusch TBH (1998) Differing effects of eelgrass Zostera marina on recruitment and growth of associated blue mussels Mytilus edulis. Mar Ecol Prog Ser 167:149-153 
Reusch TBH, Chapman ARO (1995) Storm effects on eelgrass (Zostera marina L.) and blue mussel (Mytilus edulis L.) beds. J Exp Mar Biol Ecol 192:257-271

Reusch TBH, Boström C, Stam WT, Olsen JL (1999) An ancient eelgrass clone in the Baltic Sea. Mar Ecol Prog Ser 183:301-304

Rooker JR, Holt SA (1997) Utilization of subtropical seagrass meadows by newly settled red drum Sciaenops ocellatus: patterns of distribution and growth. 158:139-149

Rooker JR, Holt GJ, Holt SA (1998) Vulnerability of newly settled red drum (Sciaenops ocellatus) to predatory fish: is early-life survival enhanced by seagrass meadows? Mar Biol 131:145-151

Schramm W (1996) The Baltic Sea and its transition zones. In: Schramm W, Nienhuis PH (eds) Marine benthic vegetation - recent changes and the effects of eutrophication. Springer-Verlag, Heidelberg, p 131-163

Shannon CE, Weaver W (1963) The mathematical theory of communication. University of Illinois Press, Urbana

Sogard SM (1984) Utilization of meiofauna as a food source by a grassbed fish, the spotted dragonet, Callionymus pauciradiatus. Mar Ecol Prog Ser 17:183-191

Sogard SM (1989) Colonization of artificial seagrass by fishes and decapod crustaceans: importance of proximity to natural seagrass. J Exp Mar Biol Ecol 133:15-37

Sousa WP (1985) Disturbance and patch dynamics on rocky intertidal shores. In: Pickett STA, White PS (eds) The ecology of natural disturbance and patch dynamics. Academic Press, Orlando, FL, p 101-124

Thrush SF, Whitlatch RB, Pridmore RD, Hewitt JE, Cummings VJ, Wilkinson MR (1996) Scale-dependent recolonization:

Editorial responsibility: Otto Kinne (Editor), Oldendorf/Luhe, Germany the role of sediment stability in a dynamic sandflat habitat. Ecology 77:2472-2487

Thrush SF, Lawrie SA, Hewitt JE, Cummings VJ (1998) The problem of scale: uncertainties and implications for softbottom marine communities and the assessment of human impacts. In: Gray JS, Ambrose W Jr, Szaniawska A (eds) Biogeochemical cycling and sediment ecology. Kluwer Academic Publishers, Dordrecht, p 195-210

Underwood AJ (1997) Experiments in ecology: their logical design and interpretation using analysis of variance. Cambridge University Press, Cambridge

Virnstein RW, Curran MC (1986) Colonization of artificial seagrass versus time and distance from source. Mar Ecol Prog Ser 29:279-288

Walters K, Bell SS (1994) Significance of copepod emergence to benthic, pelagic, and phytal linkages in a subtidal seagrass bed. Mar Ecol Prog Ser 108:237-249

Ward LG, Kemp WM, Boynton WR (1984) The influence of waves and seagrass communities on suspended particulates in an estuarine embayment. Mar Geol 59:85-108

Wilson FS (1990) Temporal and spatial patterns of settlement: a field study of molluscs in Bogue Sound, North Carolina. J Exp Mar Biol Ecol 139:201-220

Worm B, Lotze HK, Boström C, Enqvist R, Labanauskas V, Sommer U (1999) Marine diversity shift linked to interactions among grazers, nutrients and dormant propagules. Mar Ecol Prog Ser 185:309-314

Worthington DG, Ferrell DJ, McNeill SE, Bell JD (1992) Effects of the shoot density of seagrass on fish and decapods: are correlations evident over larger spatial scales? Mar Biol 112:139-146

Submitted: December 6, 1999; Accepted: May 4, 2000

Proofs received from author(s): September 20, 2000 